\title{
Chemical and Mechanical Properties Changes in Corymbia Citriodora Wood Submitted to Heat Treatment
}

\author{
Marcio Rogério da Silva ${ }^{1}$, José Otávio Brito ${ }^{2}$, José Silvio Govone ${ }^{3}$, Gilmara de Oliveira Machado ${ }^{4}$, \\ Carlito Calil Junior ${ }^{5}$, André Luis Christoforo ${ }^{6, *}$, Francisco Antonio Rocco Lahr ${ }^{5}$ \\ ${ }^{1}$ Wood and Timber Structures Laboratory (LaMEM), Engineering School of São Carlos of University of São Paulo (EESC/USP), \\ São Carlos, Brazil \\ ${ }^{2}$ Pulp Laboratory, Chemical and Energy from Department of Forest Sciences (LQCE), Piracicaba, Brazil \\ ${ }^{3}$ Department of Statistics, Applied Mathematics and Computing (DEMAC), Paulista State University (UNESP), Rio Claro, Brazil \\ ${ }^{4}$ Department of Forestry, State University of Midwest (UNICENTRO), Irati, Brazil \\ ${ }^{5}$ Department of Structures Engineering (SET), Engineering School of São Carlos of University of São Paulo (EESC/USP), \\ São Carlos, Brazil \\ ${ }^{6}$ Centre for Innovation and Technology in Composites (CITeC), Department of Civil Engineering (DECiv), Federal University of São \\ Carlos (UFSCar), São Carlos, Brazil
}

\begin{abstract}
The heat is important treatment in the wood processing. The changes are not significant in structural properties in some case, like wood drying. However, in other treatments, such heat treatment and carbonization the changes can be intense. The main purpose of this research is to investigate the influence of thermorectification process on the chemical and mechanical behavior of Corymbia citriodora (Hook.) K.D. Hill \& L.A.S. Johnson. The heat treatment was performed in a laboratorial electric furnace at 160,180 and $200{ }^{\circ} \mathrm{C}$, under inert atmosphere, using boards measuring $6 \times 16 \times 56 \mathrm{~cm}^{3}$ and the temperature in the wood pieces was controlled by thermocouples. The mechanical and chemical properties were determined to fresh and heat-treated wood. The mechanical properties were evaluated by Modulus of Rupture (MOR) and Modulus of Elasticity (MOE) in bending, and also tensile and shear strength parallel to the grain. The content of cellulose, hemicelluloses, lignin, extractives and ash were determined according to TAPPI Standard. The chemical analysis revealed that when the temperatures and time increase, the changes are ranged from 17.8 to $9.6 \%$ extractives; 30.4 to $44 \%$ lignin; 30.8 to $42.8 \%$ cellulose and 21.7 to $6 \%$ hemicelluloses. The ash content remains almost steady for all boards. The mechanical tests showed that the MOR and the tension parallel to the grain $\left(\mathrm{f}_{\mathrm{t} 0}\right)$ decreased from $36 \%$ up to $55 \%$, respectively. The stiffness properties (MOE) increased about $12 \%$, improved during thermal treatment.
\end{abstract}

Keywords Wood heat treatment, Physical and mechanical properties, Chemical analysis

\section{Introduction}

The thermal treatment of wood at low temperature is based on the principle of the mild pyrolysis, where a controlled thermal degradation of wood happens in a nitrogen atmosphere, with less than $2 \%$ of oxygen. Rectification process is defined as the result of a controlled pyrolysis that ends before initiating exothermic reactions, at about $240^{\circ} \mathrm{C}$. Submit wood to heat is a method that modifies its chemical and mechanical structure. The mean purpose of this technology is to propose an environmentally friendly way to protect wood against xylophages agent without the

* Corresponding author:

alchristoforo@yahoo.com.br (André Luis Christoforo)

Published online at http://journal.sapub.org/ijme

Copyright (C) 2015 Scientific \& Academic Publishing. All Rights Reserved using of toxic chemicals, while improving the dimensional stability and the color of wood $[1,2]$.

Changes in the strength and stiffness of thermally treated wood, under different heating methods, occur due to different chemical composition and anatomical nature of woods. Additionally, the heating procedures are not the same; as a result, the heat treatment and also the properties of thermally treated wood can vary widely. It is a fact that the influence of thermal treatment on mechanical properties of wood is complex, and the magnitude of this effect is a function of parameters such as exposure time, temperature, medium rate of heating and moisture content of wood $[3,4]$.

The thermal process causes chemical changes in the constituents of cell wall (cellulose, hemicelluloses and lignin) and extractives. The extractives, which are compound by a wide range of organic substances of low molecular mass, evaporate when exposed to heat. The oxygen and hydrogen 
content of the wood is reduced, otherwise the carbon content increase.

Hemicelluloses are more affected than other constituents of wood due to their relative lower thermal stabilities. Desacetylation of hemicelluloses produces acetic acid, which act on the depolymerization catalyst of polysaccharides. Additionally, the hemicelluloses degradation can lead to darkness of the timber. During heat process, the dehydrating of hemicelluloses induces the formation of furfural and hidroximetilfurfural.

Under heat effect, crystalline cellulose increases because of the degradation of amorphous cellulose; as a result, the accessibility of the hydroxyl groups to the water molecules decrease and the moisture content of heat treated wood is lower. At the same time, that heat produces dehydration and oxidation reaction of cellulose, the lignin suffers condensation that increases its molecular mass [5-7].

Temperature has a greater influence than time on many properties of wood. Normally, the treatment at low temperatures, for long periods, does not bring the desired modification in wood. At temperatures above $150^{\circ} \mathrm{C}$, the changes in physical and chemical properties of wood are permanent. At same time, there is a loss in strength properties of wood [4].

The changes in mechanical properties of pine wood (Pinus sylvestris L.) treated at temperatures of 120,150 and $180^{\circ} \mathrm{C}$; during 2, 6 and $10 \mathrm{~h}$, were studied by [3]. The authors found that the compression parallel to the grain and bending strength, bending stiffness, Janka hardness and impact bending strength decreased when the temperature and time of heat treatment increase. The smallest reduction in the mechanical properties was observed in the treatment at $120^{\circ} \mathrm{C}$ for $2 \mathrm{~h}$.

[8] analyzed the strength and stiffness of five species of commercial wood in Quebec, Canada, as follows: Spruce (Picea spp), Pine (Pinus spp), Fir (Abies spp), Aspen (Populus spp) and Birch (Betula spp). These wood species have been organized in different groups, at temperatures of $200^{\circ} \mathrm{C}$ or higher. For Spruce and Pine, at $212^{\circ} \mathrm{C}$, the modulus of rupture in bending (MOR) decrease in 49 and $28 \%$, respectively; additionally the banding stiffness (MOE) decreased in 14 and $5 \%$. For the Fir at $202^{\circ} \mathrm{C}$, the MOR remained stable while the MOE increased in $25 \%$. Aspen at $200^{\circ} \mathrm{C}$ dropped its MOR in $35 \%$ and increased its MOE in $15 \%$. Finally Birch, had increased both MOR and MOE in 6 and $30 \%$, respectively, at $200^{\circ} \mathrm{C}$. They concluded that the mechanical properties of the thermally treated wood increase or decrease depending on the species, the direction of solicitation (longitudinal, radial or tangential) and the heat treatment program.

The thermal degradation of the hemicelluloses produces woods with higher dimensional stability due to its lower hygroscopicity. However, this benefit is accompanied by a significant reduction in the bending strength (MOR) and bending stiffness (MOE). The compressive strength is less affected because of the small degradation of cellulose and lignin [5].
The heat-treated wood of Pinus taeda was studied by [9]. The treatment temperature was $180^{\circ} \mathrm{C}$, during 30 and 120 min., after achieve the temperature. These two different times are used to ensure the homogenization of the heat inside the wood. The treatment during $120 \mathrm{~min}$ was necessary to obtain homogeneity of the heat inside woods pieces. The results shows that the strength on compression parallel to the grain increased from 22 to $45 \%$ for the treatment at $180^{\circ} \mathrm{C}-30 \mathrm{~min}$, and $180^{\circ} \mathrm{C}-120 \mathrm{~min}$; respectively. The stiffness, according to statistical analysis, remained stable. The shear strength increased in $25 \%$ at $180^{\circ} \mathrm{C}-30 \mathrm{~min}$, and finally; the treatment at $180^{\circ} \mathrm{C}-120 \mathrm{~min}$, in accordance with the statistical analysis, was equivalent to the wood control.

The main goals of this research is to investigate and compare the changes in chemical and mechanical properties of heat treated wood of Corymbia citriodora at temperatures of 160,180 and $200{ }^{\circ} \mathrm{C}$. For better understanding how the heat treatment affects these properties, we are using the results of the MOR, MOE and tensile parallel to the grain compare to chemical composition.

\section{Material and Methods}

The specie selected for the present investigation was Corymbia citriodora (Hook.) K. D. Hill \& L. A.S. Johnson. The 18-year-old trees were obtained from a farm plantation in São Paulo state, Brazil. To have representative samples, the wood was collected by cutting boards from a trunk and the boards were then cut into test-pieces. The moisture content and density of fresh wood was $12 \%$ and $1.0 \mathrm{~g} . \mathrm{cm}^{-3}$, respectively.

The heat treatment was carried out in a laboratorial electric furnace, under dynamic nitrogen atmosphere at a heating rate of $0,033^{\circ} \mathrm{C} \cdot \mathrm{min}^{-1}$. Seven pieces of wood, with dimensions of $56 \mathrm{~cm}$ length, $16 \mathrm{~cm}$ width and $6 \mathrm{~cm}$ thick, were used by each treatment. The boards were placed inside the metal box with a lid, one over the other, in a vertical disposition. Two steel bars, $1 \mathrm{~cm}$ in diameter, were placed among the boards. This procedure was adopted to allow the free flow of the nitrogen gas around each piece of wood. Because the thermal degradation of heated wood in the presence of oxygen is higher than oxygen-free atmosphere [4], nitrogen gas was injected inside the box during all thermal treatment, in order to avoid oxidation of the timber.

The temperature control was achieved using seven thermocouples, $\mathrm{K}$ model. One of them was installed inside the oven, the other inside the metal box, and the others five were inserted in the pieces of woods. Thermocouples installed in the pieces of wood were positioned tree of them in the first piece and others two in the sixth piece. The thermocouples were positioned to measure the temperature at the geometric center and the extremity of the group of wood pieces. This procedure was adopted to provide a better homogenization of the heat throughout the pieces of wood.

The thermorectification of wood was performed on steps. First, the temperature of oven was rising from room 
temperature to $100^{\circ} \mathrm{C}$, during $40 \mathrm{~min}$. After that, the heating rate was maintained constant at $0.033^{\circ} \mathrm{C} \min ^{-1} \pm 5^{\circ} \mathrm{C}$, until obtaining the temperature for each treatment. The heat treatment was considered completed when the temperature achieved 160,180 and $200^{\circ} \mathrm{C}$ after the time of the conditioning. In the last step, to ensure homogenization of heat throughout the length of each piece of wood, it was necessary to wait the finalization of the heat treatment for a period of time that was dependent on the final temperature of the thermorectification. Finally, the oven was turned off and the temperature was reduced to room temperature using only the air circulation system of furnace.

After finish the heat treatment, to do the mechanical measurements, the boards of wood were cut in smaller pieces of $2.5 \times 2.5 \times 60 \mathrm{~cm}$. The bending strength $\left(\mathrm{MOR}=\mathrm{f}_{\mathrm{M}}\right)$, bending stiffness (MOE) also tensile and shear strength parallel to the fibers $\left(f_{t 0}\right.$ and $\left.f_{v 0}\right)$ were performed according to Brazilian standard [10], except for the size of the pieces of wood to bending tests. This last change in the size happens because the metal box had a maximum length of $60 \mathrm{~cm}$. Then, $60 \mathrm{~cm}$ were used and the dimensions of $2.5 \times 2.5 \times 60 \mathrm{~cm}$ was defined by the ratio $\mathrm{L} / \mathrm{h}=21$, and also by the maximum bending load $\left(\mathrm{M}_{\max }\right)$, as proposed by Brazilian standard [10]. The MOE was determine by the slope of the secant line in the load vs. displacement graphic at the points of $\left(\mathrm{F}_{10 \%}, \mathrm{~V}_{10 \%}\right)$ and $\left(\mathrm{F}_{50 \%}, \mathrm{~V}_{50 \%}\right)$, corresponding respectively to $10 \%$ and $50 \%$ of the bending strength. All these values were obtained at different temperature levels, according to Equations 1 and 2 .

$$
\begin{gathered}
F_{M}=M_{\max } / W_{e} \\
E_{m 0}=\frac{\left(F_{M 50 \%}-F_{M 10 \%}\right) \cdot L^{3}}{\left(v_{50 \%}-v_{10 \%}\right) \cdot 4 \cdot b \cdot h^{3}}
\end{gathered}
$$

From Equations 1 and 2, $\mathrm{M}_{\max }$ is the maximum moment applied during the test samples $(\mathrm{N} \cdot \mathrm{m}), \mathrm{W}_{\mathrm{e}}$ is the Resistance module of the cross section of the samples, given by $\mathrm{bh}^{2} / 6$ $\left(\mathrm{m}^{3}\right), \mathrm{F}_{\mathrm{M} 50 \%}$ and $\mathrm{F}_{\mathrm{M} 10 \%}$ are the loads corresponding to the bending at $50 \%$ and $10 \%(\mathrm{~N}), \mathrm{v}_{50} \%$ and $\mathrm{v}_{10 \%}$ are the displacements at $10 \%$ and $50 \%$ of the estimated maximum load (m), $\mathrm{L}$ is the distance of the wood support (m), finally, $\mathrm{b}$ and $h$ are the width and height of the cross section of sample, respectively.

The tests of tensile strength parallel to the grain were performed from the maximum tensile force $\left(\mathrm{F}_{\mathrm{t} 0 \text {, max }}\right)$ applied on samples with uniform cross section and area $\mathrm{A}$, length not less than $8 \cdot \mathrm{A}^{1 / 2}\left(\mathrm{~cm}^{2}\right)$. The extremities of the tested piece of wood are more strength than the central region, which ensure that the rupture occurs in the middle. Data were obtained for different temperature levels according to Equation 3, where $\mathrm{F}_{\mathrm{t} 0 \text {, max }}$ is the maximum tensile force applied to the samples $(\mathrm{N})$, and $\mathrm{A}$ is the cross sectional area of the middle of the samples $\left(\mathrm{cm}^{2}\right)$.

$$
f_{t 0}=F_{t 0, \max } / A
$$

For the chemical analysis, the pieces of wood were reduced to small particles enough to pass through a 42 mesh screen $(0.355 \mathrm{~mm}$ pore size $)$. The moisture content of all samples was determined before each assay. The samples were treated in a soxhlet extractor containing water and organic solvents (cyclohexane and ethanol, P.A. grade). First, the sample was extracted with ethanol for 4 hours. Next, a 1:1 cyclohexane/ethanol extraction was performed over 8 hours. Finally, the samples were subjected to a 3-hour extraction in distilled water and the fibers dried at $60^{\circ} \mathrm{C}$. The extractive content was determined by mass difference, before and after the extraction. The following analyses were done on extractive-free samples. The ash content was measured as described in standard [11]. The lignin content was determined as the sum of the insoluble and soluble lignin, using standard methods given in [12] and [13]. High performance liquid chromatography (HPLC) was used to analyze the cellulose and hemicellulose contents, as specified in standard [14]. All tests were carried out in triplicate.

Statistical analysis was realized using Minitab 16 software. Results obtained from bending strength, bending stiffness, also tensile and shear strength parallel to the grain in different temperatures are compared using analysis of variance (ANOVA) and Tukey's test, with confidence level of $95 \%$.

\section{Results and Discussions}

The thermal treatment of C. citriodora wood was performed in temperatures at 160,180 and $200^{\circ} \mathrm{C}$, with a standard deviation of $\pm 10^{\circ} \mathrm{C}$. After achieving the target temperature, for a better homogenization of the heat inside each pieces of wood, it was necessary to keep the temperature at the end point. Then, the complete time for each treatment was $150 \mathrm{~min}$ at 160 and $180^{\circ} \mathrm{C}$; and $120 \mathrm{~min}$ at $200^{\circ} \mathrm{C}$. At 160 and $180^{\circ} \mathrm{C}$, the time was higher due to lower amount of available energy inside the system. Figure 1a shows the thermal-rectification pattern at $160^{\circ} \mathrm{C}$ and Figure $1 \mathrm{~b}$ presents the amplification of the curves, for a better visualization of the last heating step at different places in the samples.

There is a pattern common to all the figures. Figure 1 shows that the target temperature was achieved with $30.96 \mathrm{~h}$. After that, it was added more $150 \mathrm{~min}$ for the homogenization heat inside of the wood pieces. Thus, the total time to end the heat treatment at $160^{\circ} \mathrm{C}$ was $33.47 \mathrm{~h}$, at 180 was $43.57 \mathrm{~h}$ and at $200^{\circ} \mathrm{C}$ was $53.17 \mathrm{~h}$.

Additionally, on each curve, Figure 1 presents a peak that indicates a decreasing in temperature. This is observed during the decline of the temperature gradient in the heating ramp, initiated at about $135^{\circ} \mathrm{C}$. Similar behavior was studied by [15], for the species of White birch (Betule papyrifera) and Quaking aspen (Populus tremuloides), during heating treatment at 120 and $220^{\circ} \mathrm{C}$. The authors showed that in temperature at about $140^{\circ} \mathrm{C}$, for both species, a reduction in the temperature gradient occurs. This variation of 
temperature is due to the moisture loss of the wood, which directly influence on the decreasing in temperature because of the heat is used also to evaporate the water of the timber. After the total removal of the water in the timber, this difference on the temperature gradient begins to decrease. Similar behavior was observed for treatments in other temperatures, at 180 and $200^{\circ} \mathrm{C}$.

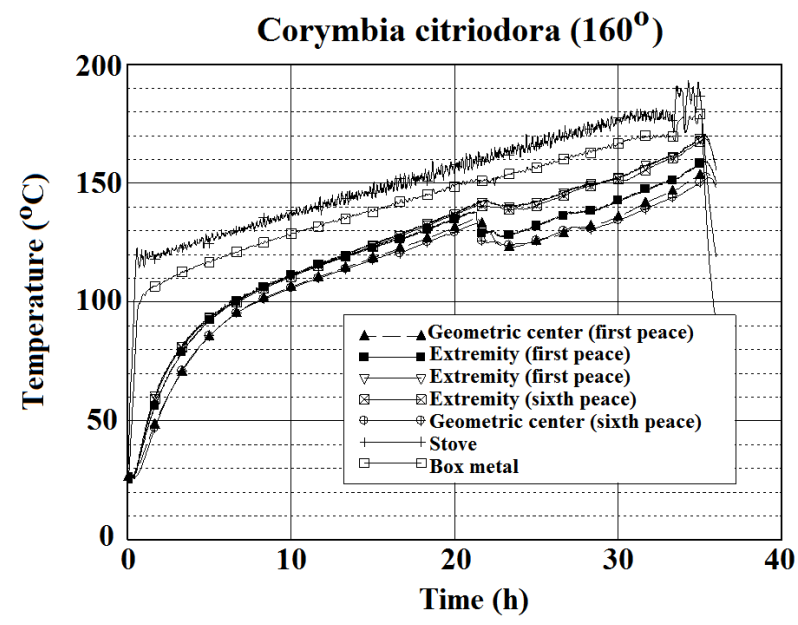

(a)

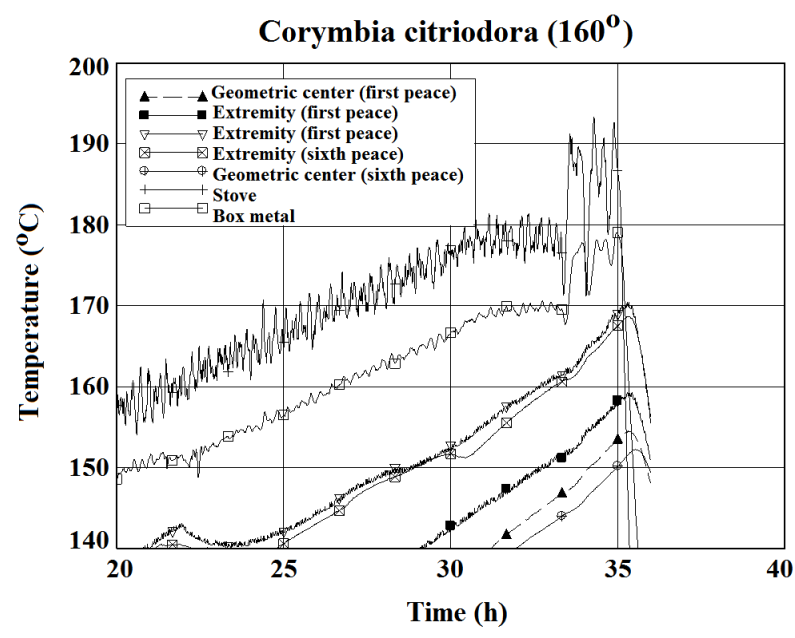

(b)

Figure 1. Heat treatment graphic (a) and amplified Curve to show the end heating step (b)

An important factor that also influences in the heat treatment of the wood is the changes in its chemical composition. Thus, the chemical characterization of $\mathrm{C}$. citriodora with and without heat treatment was determined. The results are shown in Table 1.
The higher the heating temperature of the wood, the greater was the reduction of extractive content, Table 1. When the temperature was increased up to $200^{\circ} \mathrm{C}(17.8$ to $9.6 \%$ ), the extractive content reduced by $46 \%$. This variation probably occurred by vaporization of different extractives from wood during heating. Additionally, the hydrothermolysis of hemicelluloses produces compounds of low molecular mass as acetic acid, water, formaldehyde and furfural. Furfural is a less hygroscopic compound from hemicelluloses and also from cellulose. Almost all original extractives leave wood, and new compounds from polysaccharides degradation were formed, including monosaccharides $[15,16]$.

For Eucalyptus globules, thermally treated at 190 and $200^{\circ} \mathrm{C}$ in different times; 2, 6 and 12 hours, the extractives content increased in the beginning of the process, followed by reduction [5]. The extractive content for temperatures at 120 and $180^{\circ} \mathrm{C}$ decreased to caribea Pinus and increased to Eucalyptus saligna. For all studied species, the extractive content was lowest at $200^{\circ} \mathrm{C}$. The authors concluded that these differences in behavior may be explained by differences of chemical constituents between softwood and hardwood [17]. The majority of acetic acid comes from the decomposition of hemicelluloses. Hardwoods have a higher content of hemicelluloses and acetyl groups, the hemicelluloses of hardwood has more pentoses and is more unstable than that of softwood, that has more hexoses. Thus, the extractive content can be modified depending on the wood species and the heating treatment used. About the ash content, it was similar for all samples.

The lignin content is increased by $44 \%$ with heat treatment (30.4 to $44 \%$ ). It is well known that the amount of Klason lignin increases when increasing heat treatment temperature [18-20]. This is mainly caused by thermal degradation of the hemicelluloses due to the cleavage of glycoside bonds along the chains and also at higher temperature, the amorphous region of cellulose start to breakdown. Cellulose does not undergo noticeable modifications in its crystallinity during heat treatment. Because of its cross-linking structure, lignin is more stable to thermal degradation than polysaccharides. During heat pyrolysis of lignin, condensation reactions, auto-crosslinking reactions, also contribute to the increase in the lignin content of thermal treated wood, especially at temperatures above $185^{\circ} \mathrm{C}[19,21]$. The results obtained from the scientific literature are in accordance with the results obtained in this study. The lignin content increased during heating, then the higher lignin content, $44 \%$, was obtained at $200^{\circ} \mathrm{C}$.

Table 1. Chemical characterization of thermally treated wood

\begin{tabular}{cccccc}
\hline Temperature $\left({ }^{\circ} \mathrm{C}\right)$ & Extractives & Ashes & Klason Lignin & Cellulose & Hemicelluloses \\
\hline Testemunha & $17.8 \pm 0.7$ & $0.31 \pm 0,02$ & $30.4 \pm 0.0$ & $30.8 \pm 0.4$ & $21.7 \pm 0.3$ \\
160 & $14.8 \pm 0.1$ & $0.33 \pm 0.00$ & $37.5 \pm 0.2$ & $32.4 \pm 3.6$ & $13.4 \pm 0.3$ \\
180 & $10.2 \pm 0.5$ & $0.29 \pm 0.00$ & $33.5 \pm 0.7$ & $28.6 \pm 1.5$ & $16.5 \pm 0.4$ \\
200 & $9.6 \pm 0.1$ & $0.33 \pm 0,02$ & $44.0 \pm 0.2$ & $42.8 \pm 1.7$ & $6.0 \pm 2.6$ \\
\hline
\end{tabular}

$P S$ : The mean is followed by its respective standard deviation. 
Table 2. Mechanical properties of Corymbia citriodora wood specie

\begin{tabular}{|c|c|c|c|c|c|c|}
\hline Temperature $\left({ }^{\circ} \mathrm{C}\right)$ & $\operatorname{MOR}(\mathrm{MPa})^{1}$ & Tukey $^{2}$ & $\operatorname{MOE}(\mathrm{GPa})^{1}$ & Tukey $^{2}$ & $\mathrm{f}_{\mathrm{t} 0}(\mathrm{MPa})^{1}$ & Tukey $^{2}$ \\
\hline Testemunha & $109 \pm 16$ & A & $16 \pm 2$ & $\mathrm{AB}$ & $70 \pm 10$ & A \\
\hline 160 & $69 \pm 32$ & B & $14 \pm 3$ & B & $35 \pm 17$ & B \\
\hline 180 & $80 \pm 20$ & B & $17 \pm 2$ & $\mathrm{AC}$ & $38 \pm 9$ & B \\
\hline 200 & $78 \pm 22$ & B & $18 \pm 3$ & $\mathrm{C}$ & $29 \pm 6$ & B \\
\hline
\end{tabular}

During heating, the cellulose content increased up to $38 \%$ and hemicelluloses decreased $72 \%$. Hemicelluloses are the first macromolecule to be affected during heat treatment, producing xyloses, arabinoses, galactoses and mannoses; that came from acid hydrolysis of glycoside bonds. The degradation starts by deacetylation of hemicelluloses, followed by depolymerization that is catalyzed by the release of acetic acid [16, 17, 19].

[4] and [19] describe that during heat treatment, an increase in crystalline cellulose occurs and lignin is the most stable component. On the other hand, cellulose are more stable than hemicelluloses. Celluloses has a crystalline structure and its molecules form microfibrils, which protects its chain against the attack of acids during hydrolysis. Our results also follow the standards of international publications, that also observed an increasing on cellulose and reduction on hemicelluloses when the treatment temperature increased.

The reduction of Klason lignin and cellulose and increase of hemicelluloses at $180^{\circ} \mathrm{C}$ compared to temperature at $160^{\circ} \mathrm{C}$ can also be attributed to the lower density of eucalyptus wood heat treated. The apparent density with moisture content of $0 \%( \pm 2 \%)$ was calculated for thermally untreated wood (control) and in temperatures at 160, 180 and $200^{\circ} \mathrm{C}$. The density results were $0.97 ; 0.92 ; 0.86$ and 0.89 g. $\mathrm{cm}^{-3}$, respectively. Because of the natural variability of the studied samples, the sample at $180^{\circ} \mathrm{C}$ showed lower density than wood at $160^{\circ} \mathrm{C}$. According to [22], the exothermic reactions happen between 180 and $200^{\circ} \mathrm{C}$, and occur due to the presence of secondary reactions, favored by the slow increase of the temperature and the confinement of the pyrolysis gases. These reactions will be more effective in thicker pieces of wood, where it is observed the difficulty of the gases leaving the wood porous matrix. Then, the lower wood density at $180^{\circ} \mathrm{C}$ induces the reduction in the occurrence of secondary reactions and, consequently, the less degradation of the hemicelluloses occurs.

Because of the changing in the chemical composition, mechanical properties were equally affected. The analysis of mechanical properties of wood, to bending strength and shear strength parallel to the grain, during increasing in temperature and also the statistical analysis are presented in Table 2. Data comes from average value of eighteen samples wood.

The bending stiffness (MOE) during the heat treatment was most affected at $160^{\circ} \mathrm{C}$. Treatments at 180 and $200^{\circ} \mathrm{C}$ showed similar behavior, obtained 80 and $78 \mathrm{MPa}$, respectively. The MOE increase at 180 and $200^{\circ} \mathrm{C}$, except by the group treated at $160^{\circ} \mathrm{C}$, where a decreasing of $12 \%$ was observed. According to statistical analysis by MOR, all thermally treated groups were statistically different to the control. Among the groups heat treated, all samples were statistically equivalent. Although for MOE, the statistically equivalent happen to the wood groups treated at 180 and $200^{\circ} \mathrm{C}(17$ and $18 \mathrm{GPa})$; also between the control sample and wood at $180^{\circ} \mathrm{C}$ (16 and $17 \mathrm{GPa}$ ); and finally, the control sample and wood treated at $160^{\circ} \mathrm{C}(16$ and $14 \mathrm{GPa})$.

[3] studied the mechanical properties of Hazelnut wood that was thermal treated (Corylus colurna L.). They concluded that the MOE and MOR reduced when the increase in temperature and time happen. [23] studied the Birch (Betula papyrifera) and aspen (Populus tremuloides). For Birch, the value of MOE and MOR reduced at above $200^{\circ} \mathrm{C}$; and for Aspen, the MOR decreased after $200^{\circ} \mathrm{C}$, similar to Birch behavior; however, the MOE increased to relatively low temperatures between 160 and $200^{\circ} \mathrm{C}$. The MOR and MOE of both species slightly increased, probably due to the influence of lignin content.

Depending on the adopted heat treatment process, the species studied and the direction of testing (tangential or radial), the MOR and MOE of thermally treated wood may increase or decrease without a clear pattern $[8,15,23]$. According to [16] and [24], one of the factors that leads to the loss of bending strength of wood is the hemicelluloses degradation. The stiffness is less affected due to reduced degradation of cellulose crystalline and lignin. [25] describe that during the heating the softening of the wood polymers happen and it is follow by significant changes in the mechanical properties of the material, especially the MOR, influencing the mechanical performance.

The tensile strength was altered during the action of heat. The largest losses were observed to the last treatment at $200^{\circ} \mathrm{C}$, with decreasing in $58 \%$ than the control. The treatments at 160 and $180^{\circ} \mathrm{C}$ were less affected by heat, the loss were 50 and $45 \%$, respectively. The statistical analysis presented $\mathrm{P}$-value $<0.05$. Thus, the Tukey test showed that there is statistically difference between the control and treated thermally group. However, among the groups treated with heat at 160,180 and $200^{\circ} \mathrm{C}$, all were equivalent.

Figure 2 shows the bending strength properties as function of hemicellulose content for Corymbia citriodora wood specie. 


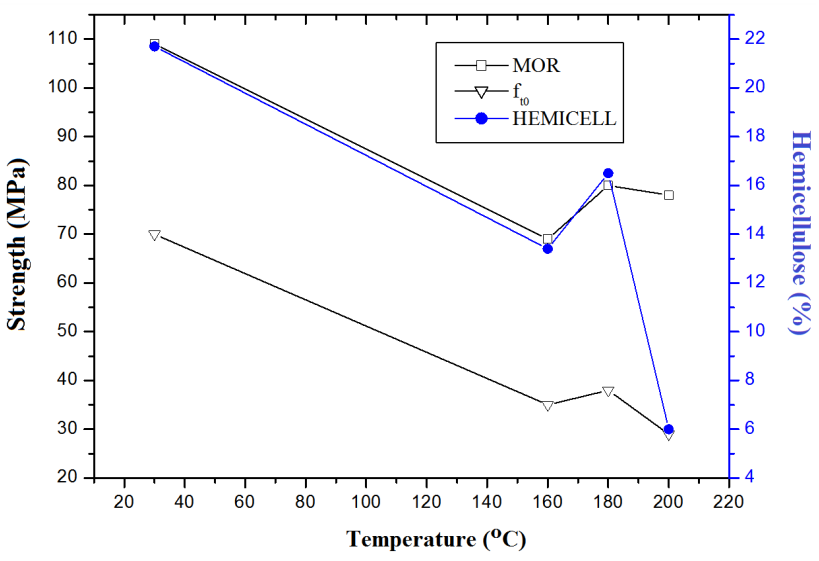

Figure 2. Strength properties due to the hemicellulose content

As described by [5] and [24], hemicellulose degradation leads to loss of strength of the timber. This fact is clearly demonstrated with the use of Figure 2, when an increase in hemicellulose content happen at $180^{\circ} \mathrm{C}$, an increase in bending and tensile strength are also observed.

\section{Conclusions}

The thermal rectification carried out at different temperatures and modifies the chemical and mechanical properties of $\mathrm{C}$. citriodora wood. The heat treatment process was adequate to the proposal of this work, with a standard deviation of $\pm 10^{\circ} \mathrm{C}$. The extractive content was decreased with increasing temperature. The ash content remained stable during all thermal treatments and lignin content increased when the temperature increased. The properties of bending and shear strength were affected by the action of heat, and the decrease in hemicelluloses content was mainly responsible. The MOE had a small increased during treatment, and this was probably due to the increase in the content of crystalline cellulose and lignin. Statistical analysis showed that the statistically equivalent changes caused by the action of heat compared to the control. In general, the greater the severity of heat treatment, the greater the changes in the chemical and mechanical properties of wood.

\section{ACKNOWLEDGEMENTS}

The authors would like to acknowledge FAPESP (Fundação de Amparo à Pesquisa do Estado de São Paulo) for the financial support given to this research. Also LaMEM (Laboratório de Madeiras e Estrutura de Madeiras), LQCE (Laboratório de Química, Energia e Celulose) and IQSC (Instituto de Química de São Carlos) for providing laboratory support.

\section{REFERENCES}

[1] Borges, L. M.; Quirino, W. F. Higroscopicidade da madeira de Pinus caribaea var.hondurensis tratado térmicamente. Revista Biomassa \& Energia, v.1, n.2, p.173-182, 2004.

[2] Silva, M. R. Efeito do tratamento térmico nas propriedades químicas, físicas e mecânicas em elementos estruturais de Eucalipto citriodora e Pinus taeda. 2012. 222 f. Tese (Doutorado em Ciências e Engenharia de Materiais), Universidade de São Paulo. São Carlos, 2012.

[3] Korkut, S.; Hiziroglu, S. Effect of heat treatment on mechanical properties of hazelnut wood (Corylus colurna L.). Materials and Design, v.30 p.1853-1858, 2009.

[4] Yildiz, S. et al. Mechanical and chemical behavior of spruce wood modified by heat. Building and Environment, n.41, p. 1762-1766, 2006.

[5] Esteves, B. et al. Extractive composition and summative chemical analysis of thermally treated eucalypt wood. Holzforschung, v.62, p. 344-351, 2008.

[6] Pétrissans, M. et al. Wettability of heat-treated wood. Holzforschung, v.57, n.3, p.301-307, 2003.

[7] Wahl, P. et al. Effect of heat-treatment on scattering of laser light from wood grains. Holz Roh-Werkstoff, v.62, n.5, p.343-345, 2004

[8] Shi, J. L. et al. Mechanical behaviour of Québec wood species heat-treated using Thermo Wood process. Holz Roh-Werkstoff, v.65, p.255-259, 2007.

[9] Silva, M. R. et al. Propriedades mecânicas do Pinus taeda tratado termicamente. In: XIII Encontro Brasileiro em Madeiras e em Estruturas de Madeira (EBRAMEM). Vitória, ES, Brasil. Anais, Vitória, ES: UFES, 8 p. CD-ROM, 2012.

[10] Associação Brasileira de Normas Técnicas - ABNT NBR 7190. Projeto de estruturas de madeira, Rio de Janeiro, 107 p., 1997.

[11] Tappi Standard Methods. T 211 om-93. Ash in wood. Atlanta, Tappi Press, 1985.

[12] Tappi Standard Methods. T 222 om-98. Acid-insoluble lignin in wood and pulp. Atlanta, Tappi Press, 1999.

[13] Tappi Standard Methods. T 250. Acid-soluble lignin in wood and pulp. Atlanta, Tappi Press, 1985.

[14] Tappi Standard Methods. T 249. cm-85. Carbohydrate composition of extractive free wood and wood pulp by gas-liquid chromatography. Atlanta, Tappi Press, 1985.

[15] Poncsak, S. et al. Effect of high temperature treatment on the mechanical properties of birch (Betula papyrifera). Wood Science and Technology, v.40, p.647-663, 2006.

[16] Esteves, B. et al. Chemistry and ecotoxicity of heat-treated pine wood extractives. Wood Science and Technology. n.45, p.661-676, 2011.

[17] Brito J. O. et al. Chemical composition changes in eucalyptus and pinus woods submitted to heat treatment. Bioresource Technology. n.99, p.8545- 8548, 2008.

[18] Windeisen, E. et al. Chemical changes during the production of thermo-treated beech wood. Wood Science and Technology. v.41, p.523-536, 2007.

[19] Boonstra, M. J.; Tjeerdsma, B. Chemical analysis of heat treated softwoods. Holzforschung, v.64, p.204-211, 2006. 
[20] Repellin, V.; Guyonnet, R. Evaluation of heat-treated wood swelling by differential scanning calorimetry in relation to chemical composition. Holzforschung. V.59, p.28-34, 2005.

[21] Brosse, N. et al. Investigation of the chemical modifications of beech Wood lignin during heat treatment. Polymer Degradation and Stability. n.95, p.1721-1726, 2010.

[22] Rousset, P. Choix et validation experimentale d'un modele de pyrolyse pour le bois traite par haute temperature: de la micro-particule au bois massif. [These]. École Nationale du Génie Rural des Eaux et des Forêts. 203 p., 2004.
[23] Kocaefe, D. et al. Effect of thermal treatment on the mechanical composition and mechanical properties of Birch and Aspen. BioResources Technology, v.3, n.2, p.517-537, 2008.

[24] Windeisen, E. et al. Relations between chemical changes and mechanical properties of thermally treated wood. Holzforschung, v. 63, p. 773-778, 2008.

[25] Figueroa, M. J. M.; Moraes, P. D. Comportamento da Madeira a temperaturas elevadas. Ambiente Construído, Porto Alegre, v. 9, n. 4, p. 157-174, out./dez. 2009. 